\title{
KAJIAN AKTIVITAS ANTIOKSIDAN MIKROKAPSUL EKSTRAK KULIT TERONG UNGU (Solanum melongena L)
}

\section{[Study of Antioxidant Activity of Purple Eggplant (Solanum melongena L) Peel Extract Microcapsule]}

\author{
Efin Lestari ${ }^{1}$, Ni Ketut Sumarni ${ }^{1 *}$, Mappiratu ${ }^{1}$ \\ 1) Jurusan Kimia, Fakultas MIPA, Universitas Tadulako, Palu \\ Jl. Soekarno Hatta Km.9, Kampus Bumi Tadulako Tondo Palu, Telp. 0451- 422611 \\ *)Coresponding author: syahparawan@gmail.com
}

Diterima 6 Desember 2019, Disetujui 28 Desember 2019

\begin{abstract}
Study about antioxidant activity of microcapsule of purple eggplant (Solanum melongena $\mathrm{L}$ ) peel extract has ben done. The research aimed to find the best $\mathrm{pH}$ and coating ratio for yielding microcapsule with the highest antioxidant activity. It was done by applying 5 levels of both $\mathrm{pH}$ varration of $2,3,4,5,6$ and maltodextrin ratio of $1: 1,2: 1,3: 1,4: 1,5: 1(\mathrm{w} / \mathrm{v})$. The determination of antioxidant activity was done by DPPH method. The result showed that at $\mathrm{pH} 2$ and $1: 1$ of maltodextrin coating ratio were the best condition to yield the highest antioxidant activity i.e $32.54 \%$ and $96.31 \%$, respectively.
\end{abstract}

Keywords : Purple eggplant peel, maltodextrin, microcapsule, antioxidant activity

\begin{abstract}
ABSTRAK
Kajian tentang aktivitas antioksidan mikrokapsul ekstrak kulit terong ungu (Solanum melongena $\mathrm{L}$ ) telah dilakukan. Penelitian bertujuan untuk mengetahui $\mathrm{pH}$ terbaik ekstrak kulit terong ungu yang menghasilkan aktivitas antioksidan tertinggi dan rasio penyalut maltodekstrin terhadap ekstrak kulit terong ungu terbaik yang menghasilkan mikrokapsul dengan aktivitas antioksidan tertinggi. Pengaruh $\mathrm{pH}$ terhadap ekstrak kulit terong ungu diterapkan 5 tingkatan yaitu $\mathrm{pH} 2,3,4,5$, dan 6, sedangkan pengaruh rasio maltodekstrin terhadap ekstrak kulit terong ungu diterapkan masing-masing 1:1, 2:1, 3:1, 4:1, dan 5:1 (b/v). Penentuan aktivitas antioksidan dilakukan menggunakan metode DPPH. Berdasarkan hasil penelitian diperoleh $\mathrm{pH}$ terbaik yang menghasilkan aktivitas antioksidan tertinggi pada $\mathrm{pH} 2$ sebesar $32,54 \%$ sedangkan untuk perbandingan rasio ekstrak kulit terong ungu tersalut maltodekstrin diperoleh aktivitas antioksidan tertinggi (96,31\%) pada rasio 1:1 (b/v).
\end{abstract}

Kata Kunci : Kulit terong ungu, maltodekstrin, mikrokapsul, aktivitas antioksidan 


\section{LATAR BELAKANG}

Terong ungu (Solanum melongena L) merupakan tanaman yang sudah lama dikenal di Indonesia, tumbuhan penghasil buah yang dijadikan sayuran ini berasal dari India dan Srilanka. Selain sebagai bahan makan terong ungu juga dapat menjadi pewarna makanan dan memiliki khasiat untuk kesehatan, karena di dalam terong ungu terdapat pigmen antosianin yang berperan sebagai antioksidan, menurunkan kadar kolestrol darah dan sebagai pewarna makanan (Basnuy et al., 2012 dalam Silitonga et al., 2014).

Antosianin adalah bagian senyawa fenol yang tergolong flavonoid. Menurut (Durst dan Wrolstad, 2005 dalam Yudiono, 2011), antosianin jumlahnya sekitar 90 $96 \%$ dari total senyawa fenol. Pigmen ini berperan terhadap timbulnya warna merah hingga biru pada beberapa bunga, buah, dan daun. Antosianin bersifat polar sehingga dapat dilarutkan pada pelarut polar seperti etanol, aceton, dan air (Yudiono, 2011). Selain itu, antosianin juga memiliki kemampuan sebagai antimutagenik dan antikarsinogenik terhadap mutagen dan karsinogen yang terdapat pada bahan pangan dan produk olahannya (Jusuf, 2008 dalam Ashari, 2010).

Senyawa antioksidan juga memiliki peranan yang sangat penting. Berbagai bukti ilmiah menunjukan bahwa senyawa antioksidan dapat mengurangi resiko berbagai penyakit kronis seperti kanker dan penyakit jantung koroner. Karakter utama senyawa antioksidan adalah kemampuannya menangkap radikal bebas (Prakash, 2001).

Sadivola (2006) dalam Silitonga et al. (2014) mengemukakan bahwa kandungan antosianin yang dominan dalam kulit terong ungu adalah delphinidin 3-rutisinode yang merupakan pigmen berwarna ungu. Pigmen antosianin lebih stabil dalam kondisi asam dari pada kondisi basa dan netral dan tidak stabil dengan cahaya panas dan dengan logam tertentu. Mikroenkapsulasi termasuk salah satu cara untuk meningkatkan kestabilan suatu senyawa antosianin (delphinidin 3rutisinode).

Mikroenkapsulasi merupakan teknik penyalutan suatu bahan aktif oleh bahan penyalut. Lapisan ini bertujuan untuk melindungi bahan aktif dari kerusakan karena sensitifitas terhadap cahaya, serta dapat menutupi rasa atau aroma yang tidak di inginkan dari bahan aktif (Hassanah, 2011 dalam Silitonga et al., 2014). Mikrokapsul pigmen kulit terong dalam penelitian ini dilakukan dengan menggunakan bahan penyalut maltodekstrin, karena maltodekstrin termasuk bahan penyalut yang banyak digunakan dalam mikroenkapsulasi, karena kemampuannya dalam membentuk emulsi dan viskositasnya rendah (Ranny, 2011).

Metode yang digunakan pada penelitian ini yaitu freez dryng, dengan tujuan untuk mendapatkan enkapsulat dalam bentuk serbuk. Menurut 
Furnawanthi (2002) pembuatan bubuk secara freeze drying, terjadi pada suhu dan tekanan yang sangat rendah. Dengan suhu rendah, komponen yang mudah rusak atau sensitif terhadap panas dapat dipertahankan dan mempunyai sifat rekonstitusi yang baik.

Pada penelitian Silitonga et al. (2014) kondisi optimum enkapsulasi pigmen antosianin kulit terong ungu adalah pada konsentrasi maltodekstrin $50 \%(\mathrm{~b} / \mathrm{v})$ dalam pelarut pembawa dengan kecepatan pengadukan $600 \mathrm{rpm}$ dimana diperoleh efisiensi tertinggi yaitu 63,85\%. Fotodegradasi oleh sinar UV-C dan polikromatis dilaporkan bahwa degradasi pigmen antosianin dalam enkapsulat oleh cahaya UV-C 6,25 kali lebih cepat daripada penyinaran dengan cahaya polikromatis, waktu paruh $\left(\mathrm{t}_{1 / 2}\right)$ masingmasing selama 27,72 dan 173,25 jam.

Penelitian Hidayah et al. (2014), tentang uji stabilitas pigmen dan antioksidan ekstrak zat warna alami kulit buah naga melaporkan bahwa perlakuan terbaik pada ekstraksi stabilitas zat warna antosianin stabil pada $\mathrm{pH}$ asam dari $\mathrm{pH} 2$ 5 , pada suhu $80^{\circ} \mathrm{C}$ dan pengaruh lama penyinaran lampu membuat zat warna antosianin menjadi tidak stabil. Kadar aktivitas antioksidan pada antosianin dari kulit buah naga sebesar $76,71 \%$.

Berdasarkan uraian tersebut maka perlu dilakukan variasi $\mathrm{pH}$ dan variasi rasio ekstrak kulit terong ungu terhadap maltodekstrin yang menghasilkan aktivitas antioksidan tertinggi.

\section{METODE PENELITIAN}

\section{Bahan dan Peralatan}

Bahan dasar yang digunakan dalam penelitian ini adalah buah terong ungu (solanum melongena L), Bahan lain sebagai bahan pengekstrak dan bahan kimia untuk analisis mencakup etanol 96 $\%$, Asam asetat glasial ( $\mathrm{pH} 2,3,4,5$, dan 6), maltodekstrin, 1,1-difenil-2-pikrilhidrazil (DPPH), aquades, aluminium foil dan kertas saring, kertas indikator $\mathrm{pH}$.

Peralatan yang digunakan meliputi pengiris wortel, rotari vakum evaporator, oven, blender, talang aluminium, spektrofotometer UV-Vis (Perkinelmer), kuvet, mesin kocok, dan neraca analitik.

\section{Prosedur Penelitian}

\section{Ekstraksi kulit terong ungu}

Ekstraksi pigmen kulit teong ungu mengacu pada penelitian Aer et al., 2013. Kulit terong ungu (Solanum melongena $\mathrm{L}$ ) diiris kecil-kecil dan dikeringkan di dalam oven vakum suhu $50^{\circ} \mathrm{C}$ selama 36 jam. Kulit terong ungu dihancurkan dengan blender, kemudian diayak sehingga diperoleh tepung kulit terong ungu. Tepung kulit terong ungu ditimbang sebanyak $100 \mathrm{~g}$ kemudian dimasukkan kedalam gelas kimia dan ditambahkan asam asetat (1:10) pada berbagai $\mathrm{pH}(\mathrm{pH}$ 2, 3, 4, 5, dan 6). Selanjutnya dimaserasi selama 24 jam. Kemudian disaring sampai filtrat dan residunya terpisah secara sempurna. Filtrat yang dihasilkan kemudian dipekatkan menggunakan evaporator pada suhu $70^{\circ} \mathrm{C}$. Ekstrak pekat 
yang dihasilkan kemudian ditepatkan volumenya hingga $25 \mathrm{ml}$. Parameter yang diamati adalah aktivitas antioksidan dari masing-masing $\mathrm{pH}$.

\section{Mikroenkapsulasi ekstrak kulit terong ungu (Sumarni et al., 2018)}

Mikroenkapsulasi dilakukan menggunakan metode pengering beku (Freeze Dryer). Perlakuan yang diterapkan adalah variasi rasio antara maltodekstrin dan ekstrak pekat kulit terong ungu, yakni : 1:1 (A); 2:1 (B); 3:1 (C); 4:1 (D); dan 5:1 (E) atas dasar berat/volume $(\mathrm{b} / \mathrm{v})$. Ekstrak pekat kulit terong ungu dicampur dengan maltodekstrin dalam gelas kimia dengan perbandingan sesuai perlakuan, kemudian diaduk dengan magnetik stirrer selama 1 jam selanjutnya disimpan pada suhu beku $\left(-20^{\circ} \mathrm{C}\right)$ selama 24 jam. Enkapsulat yang terbentuk kemudian dikeringkan menggunakan Freeze Dryer.

\section{Uji aktivitas antioksidan}

Ekstrak dan mikrokapsul masingmasing ditentukan aktivitas antioksidannya menggunakan metode spektrofotometri dengan pereaksi DPPH. Ekstrak dan Mikrokapsul masing-masing dilarutkan dengan etanol untuk mendapatkan larutan 200 ppm. Larutan yang telah dibuat dipipet sebanyak $2 \mathrm{ml}$ dan ditambahkan dengan $2 \mathrm{ml}$ larutan DPPH $50 \mu \mathrm{M}$. Campuran dihomogenkan dan dibiarkan selama 30 menit di tempat gelap, kemudian diukur serapannya pada panjang gelombang $517 \mathrm{~nm}$. Pengujian juga dilakukan terhadap blanko (larutan DPPH), nilai absorbansi yang diperoleh digunakan untuk menentukan \% inhibisi dengan persamaan berikut :

$$
\% \text { Inhibisi }=\frac{\text { Abs. blanko }- \text { Abs. sampel }}{\text { Abs.blanko }} \times 100 \%
$$

\section{HASIL DAN PEMBAHASAN}

\section{Ekstrak Kulit Terong Ungu}

Proses ekstraksi dilakukan dengan cara maserasi menggunakan pelarut asam asetat dari berbagai $\mathrm{pH}(2,3,4,5$, dan 6), karena asam asetat bercampur dengan mudah dengan pelarut polar lainnya.

Setyaningrum

(2010) menyatakan bahwa, ekstraksi senyawa golongan flavonoid dianjurkan dilakukan pada suasana asam karena asam berfungsi mendenaturasi membran sel tanaman, kemudian melarutkan pigmen antosianin sehingga dapat keluar dari sel, serta dapat mencegah oksidasi flavonoid. Senyawa golongan flavonoid termasuk senyawa polar dan dapat diekstraksi dengan pelarut yang bersifat polar pula.

Menurut Fellow (1994 dalam Lazuardi, 2010) proses pelarutan suatu senyawa yang terdapat di dalam bahan baku selama proses ekstraksi dipengaruhi oleh kemurnian pelarut, suhu pelarut, ukuran partikel-partikel bahan yang diekstraksi, sifat kimia pelarut dan zat terlarut, waktu ekstraksi atau kontak antara bahan dengan pelarut, kadar air bahan yang diekstraksi dan sistem ekstraksi yang dilakukan. 
Proses ekstraksi dilakukan selama 24 jam, dengan pelarut asam asetat dari $\mathrm{pH}$ 2, 3, 4, 5, dan 6, bertujuan untuk mengeluarkan/mengekstrak semua antosianin yang terkandung di dalam kulit terong ungu, memperluas permukaan kulit terong ungu yang akan mempermudah antosianin untuk larut dalam pelarut. Metode maserasi dipilih karena faktor kerusakan zat aktif lebih kecil karena dalam metode ini tidak menggunakan panas yang dapat merusak zat aktif yang ditarik. Penekanan utama dalam metode ini adalah tersedianya waktu kontak yang cukup antara pelarut dengan jaringan yang terekstraksi. Maserasi dilakukan dengan cara merendam serbuk simplisia dalam cairan pelarut. Pelarut akan menembus dinding sel dan masuk kedalam rongga sel yang mengandung zat aktif (Hanum, 2000). Dari proses maserasi selama 24 jam maserat yang diperoleh kemudian di uapakan dengan alat rotary evaporator dengan tujuan untuk mendapatkan ekstrak pekat.

\section{Aktivitas Antioksidan Ekstrak Kulit Terong Ungu dengan Metode DPPH}

Aktivitas antioksidan ekstrak kulit terong ungu di uji dengan menggunakan metode DPPH dengan spektrofotometri UV-Vis pada panjang gelombang maksimum $517 \mathrm{~nm}$. Pengukuran aktivitas antioksidan dengan metode DPPH merupakan metode pengukuran antioksidan yang sederhana, cepat dan tidak membutuhkan banyak reagen seperti halnya metode lain. Hasil pengukuran dengan metode DPPH menunjukkan kemampuan antioksidan sampel secara umum, tidak berdasar jenis radikal yang dihambat (Juniarti et al.., 2009). Adanya aktivitas antioksidan dari sampel mengakibatkan perubahan warna pada larutan DPPH dalam etanol yang semula berwarna violet pekat menjadi kuning pucat (Andayani 2008).

Pengujian aktivitas antioksidan diawali dengan penentuan \% inhibisi ekstrak kulit terong ungu dari berbagai $\mathrm{pH}$. Dimana \% inhibisi tertinggi yaitu pada $\mathrm{pH}$ 2 sebesar 32,54 \% dan \% inhibisi terendah pada pH 5 sebesar 1,939\%. Nilai persen inhibisi tersebut dapat dilihat dari kurva hubungan antara $\mathrm{pH}$ dan persen inhibisi :

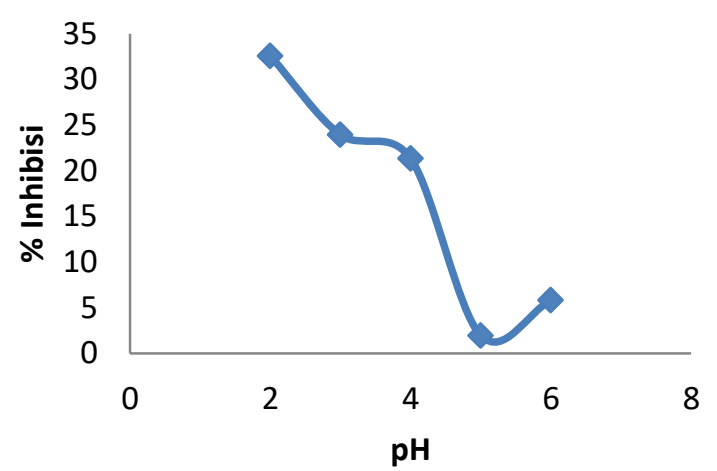

Gambar 1 Kurva hubungan presentase inhibisi terhadap $\mathrm{pH}$.

Aktivitas antioksidan tertinggi terdapat pada pH 2 (Gambar 1), hal ini menandakan bahwa keadaan yang semakin asam akan menyebabkan semakin banyak dinding sel vakuola yang pecah sehingga pigmen dari kulit terong ungu semakin banyak yang terekstrak maka kandungan antioksidannya semakin 
tinggi, sehingga berdampak juga pada tingkat penghambatan radikal bebas yang dilakukan oleh zat antioksidan tersebut.

Pada kondisi pH 5 terjadi penurunan secara signifikan, hal ini mungkin dikarenakan peningkatan $\mathrm{pH}$ menunjukkan warna antosianin memudar karena kation flavilium yang berwarna merah mengalami hidrasi menjadi karbinol yang tidak berwarna, sehingga pada $\mathrm{pH}$ tinggi senyawa ini cepat terhidrolisis menjadi kalkon yang terionisai sempurna. Hal inilah yang menyebabkan antosianin mudah rusak pada kondisi $\mathrm{pH}$ tinggi. Selain itu antosianin juga dapat terdegradasi oleh adanya oksigen dan oksidasi enzimatik, misalnya polifenol oksidase yang menghasilkan perubahan warna yang signifikan. Hal ini sesuai dengan penelitian Hanum (2000), bahwa kondisi konsentrat beras ketan hitam pada $\mathrm{pH}$ 5,5 menunjukkan penurunan kadar pigmen yang lebih besar atau paling tidak stabil dibandingkan dengan kondisi $\mathrm{pH}$ dibawah yaitu $\mathrm{pH} 3,5$ dan 4,5. Pada $\mathrm{pH} 6$ terjadi kenaikan namun tidak secara signifikan hal ini mungkin dikarenakan adanya zat aktif lain yang ikut terekstrak pada proses ekstraksi berlangsung.

Hasil yang diperoleh dari analisis sidik ragam ekstrak kulit terong ungu dari berbagai $\mathrm{pH}$, menunjukan variasi $\mathrm{pH}$ berpengaruh nyata terhadap aktivitas antioksidan. Hasil analisis lanjut menggunakan uji BNJ pada taraf $5 \%$ (Tabel 1), menunjukan aktivitas antioksidan berbeda nyata pada setiap $\mathrm{pH}$ yang dihasilkan. Pada hasil uji menunjukkan $\mathrm{pH} 2,3$, dan 4 berbeda tidak nyata satu sama lain dengan aktivitas tertinggi $32,54 \%$ pada $\mathrm{pH} 2$.

Tabel 1 Uji BNJ a $=0,05$ Data aktivitas antioksidan ekstrak kulit terong ungu dari berbagai $\mathrm{pH}$

\begin{tabular}{ccc}
\hline Variasi pH & $\begin{array}{c}\text { Rata-rata } \\
\text { Aktivitas } \\
\text { antioksidan } \\
(\%)\end{array}$ & $\begin{array}{c}\text { BNJ a }= \\
\mathbf{0 , 0 5}\end{array}$ \\
\hline 2 & $32,54 \mathbf{c}$ & \\
3 & $23,91 \mathbf{c}$ & 12,9 \\
4 & $21,32 \mathbf{c}$ & \\
5 & $1,939 \mathbf{a}$ & \\
6 & $5,801 \mathbf{a b}$ & \\
\hline
\end{tabular}

Keterangan: Angka-angka yang diikuti huruf yang sama pada setiap kolom menunjukkan berbeda tidak nyata pada taraf $5 \%$.

Untuk perlakuan yang terdapat pada kolom yang berbeda mengidentifikasikan perbedaan yang signifikan atau berbeda nyata, dan perlakuan yang terdapat pada kolom yang sama mengidentifikasikan perbedaan yang tidak signifikan atau berbeda tidak nyata.

\section{Aktivitas Antioksidan Mikroenkapsul Ekstrak Kulit Terong Ungu}

Mikroenkapsulasi pigmen kulit terong dalam penelitian ini dilakukan dengan menggunakan bahan penyalut maltodekstrin menggunakan metode freez dryng, dengan tujuan untuk mendapatkan enkapsulat dalam bentuk serbuk. Menurut Furnawanthi (2002) pembuatan bubuk secara freeze drying, bekerja pada suhu dan tekanan yang sangat rendah. Dengan suhu rendah, komponen yang mudah rusak atau sensitif terhadap panas dapat dipertahankan dan mempunyai sifat 
rekonstitusi yang baik. Dalam penelitian ini pembuatan mikrokapsul dilakukan dengan variasi rasio antara penyalut maltodekstrin dan ekstrak kulit terong ungu, dimana perbandingan rasionya adalah $1: 1 ; 2: 1$; $3: 1 ; 4: 1$; dan 5:1. Pemilihan maltodekstrin yaitu karena memiliki sifat sebagai penyalut yang baik dan kemampuannya dalam membentuk emulsi dan viskositas yang rendah (Ranny, 2011).

Pengujian aktivitas antioksidan terhadapat mikrokapsul dari ekstrak kulit terong ungu tersalut maltodekstrin dengan berbagai rasio menunjukan presentase inhibisi tertinggi yaitu pada rasio 1:1 sebesar $96,31 \%$ dan terendah pada rasio $5: 1$ sebesar $26,96 \%$. Nilai persen inhibisi tersebut dapat dilihat dari kurva hubungan antara rasio (b/v) dan persen inhibisi:

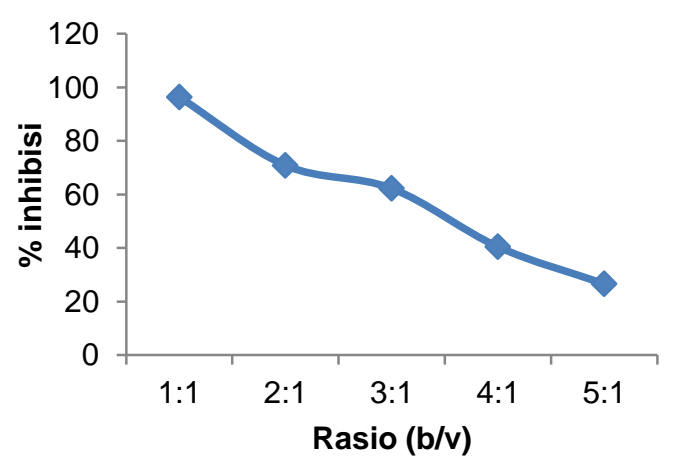

Gambar 2 Kurva hubungan presentase inhibisi terhadap rasio

Semakin tinggi penambahan maltodekstrin terhadap ekstrak pekat kulit terong ungu maka semakin rendah presentase inhibisi yang didapatkan (Gambar 2). Hal ini dikarenakan bahan pengikat maltodekstrin mempunyai kemampuan emulsifikasi dan retensi komponen volatile yang rendah (Madene et al.., 2005). Hal tersebut membuat maltodekstrin tidak dapat membentuk lapisan yang dapat melindungi produk dari proses perubahan destruktif, sehingga membuat aktivitas antioksidan menurun.

Sugindro, et al. (2008) menyatakan, bahwa semakin banyak maltodekstrin yang ditambahkan maka viskositasnya menjadi rendah. Viskositas emulsi yang rendah sebelum pengeringan membuat lapisan kulit (shell) yang terbentuk menjadi tidak begitu kuat, sehingga material inti menjadi kurang terlindungi dan karena hal tersebut maka banyak komponen yang mudah menguap hilang ketika proses pengeringan berlangsung. Dengan demikian, hasil penelitian sudah sesuai dengan teori, bahwa semakin besar rasio maltodekstrin yang digunakan aktivitas antioksidan yang di dapatkan semakin kecil. Berdasarkan penelitian kania (2015) tentang pengaruh rasio bahan pengikat terhadap karakteristik fisik dan kimia granul minuman fungsional, menyatakan bahwa semakin besar rasio gum arab yang digunakan, aktivitas antioksidan yang ada lebih besar dari pada aktivitas antioksidan pada variasi rasio bahan pengikat lainnya. variasi rasio bahan pengikat gum arab dan maltodekstrin dengan perbandingan 75\%:25\% memiliki aktivitas antioksidan tertinggi yaitu sebesar $27,838 \%$.

Berdasarkan hasil penelitian Purnomo (2014) bahwa Aktivitas antioksidan pada bubuk pewarna daun jati tanpa menggunakan penyalut lebih 
rendah bila dibandingkan dengan aktivitas antioksidan mikroenkapsulan dengan menggunakan ratio kombinasi penyalut. Hal ini disebabkan karena penambahan penyalut sangat mempengaruhi stabilitas aktivitas antioksidan. Penyalut dapat melindungi senyawa-senyawa antioksidan pada sampel, sehingga selama proses spray drying dapat meminimalisir kerusakan antioksidan. Aktivitas penangkapan radikal bebas tertinggi mengalami peningkatan kombinasi penyalut pada perbandingan rasio 1:1:1 (penyalut maltodekstrin, karagenan, dan whey (MKW)).

Tabel 2 Uji BNJ $a=0,05$ Data aktivitas antioksidan mikrokapsul ekstrak kulit terong ungu tersalut maltodekstrin dari berbagai rasio

\begin{tabular}{ccc}
\hline $\begin{array}{c}\text { Rasio penyalut } \\
\text { maltodekstrin } \\
\text { dan ekstrak } \\
\text { kulit terong } \\
\text { ungu (b/v) }\end{array}$ & $\begin{array}{c}\text { Rata-rata } \\
\text { Aktivitas } \\
\text { antioksidan } \\
\text { (\%) }\end{array}$ & $\begin{array}{c}\text { BNJ a }= \\
\mathbf{0 , 0 5}\end{array}$ \\
\hline $1: 1$ & $96,31 \mathbf{b}$ & \\
$2: 1$ & $70,83 \mathbf{a b}$ & \\
$3: 1$ & 62,21 ab & \\
$4: 1$ & 40,42 ab & 59,4 \\
$5: 1$ & $26,60 \mathbf{a}$ & \\
\hline
\end{tabular}

Keterangan: Angka-angka yang diikuti huruf yang sama pada setiap kolom menunjukan berbeda tidak nyata pada taraf $5 \%$.

Hasil analisis sidik ragam menunjukan perbandingan rasio berpengaruh nyata terhadap presentase inhibisi. Hasil analisis lanjut menggunakan uji BNJ taraf $5 \%$ menunjukan rasio 2:1, 3:1, dan $4: 1$ berbeda tidak nyata, sedangkan pada rasio $1: 1$ dan 5:1 berbeda nyata (Tabel 2). Perbedaan tersebut dikarenakan adanya penambahan maltodekstrin secara bertahap sehingga mengakibatkan menurunnya aktivitas antioksidan.

\section{KESIMPULAN}

Ekstrak kulit terong ungu menghasilkan \% inhibisi tertinggi yaitu pada pH 2 sebesar 32,54\%. Rasio ekstrak kulit terong ungu tersalut maltodekstrin 1:1 (b/v) menghasilkan \% Inhibisi tertinggi sebesar $96,31 \%$.

\section{UCAPAN TERIMAKASIH}

Terimakasih penulis sampaikan kepada Dewi Indriyani, S.Si yang telah membantu dalam keberlangsungan penelitian.

\section{DAFTAR PUSTAKA}

Ashari, A. 2010. Ekstraksi dan Karakterisasi Antosianin dari Ubi Banggai Maku Makulolong. Skripsi Palu: Fakultas Matematika dan IImu Pengetahuan Alam Universitas Tadulako.

Andayani, R. Y., Lisawati dan Maimunah. 2008. Penentuan Aktivitas Antioksidan, Kadar Fenolat Total dan Likopen Pada Buah Tomat (Solanum Lycopersicum L). Jurnal Sains dan Teknologi Farmasi. 13(1).

Aer, BN.; Wullur, AC. dan citraningtyas, G. 2013. Uji Efek Ekstrak Etanol Kulit Terong Ungu (Solanum Melongena L) Terhadap Kadar Gula Darah Pada Tikus Putih Jantan Galur Wistar (Rattus norvegicius), J. Pharmacon., 2(4).

Setyaningrum E. N. 2010. Efektivitas Penggunaan Jenis Asam dalam Proses Ekstraksi Pigmen Antosianin Kulit Manggis (Garcinia 
mangostana L.) dengan Penambahan Aseton 60\%. Skripsi. Surakarta: Program Studi Teknologi Hasil Pertanian, Fakultas Pertanian, Universitas Sebelas Maret.

Furnawanthi, 2002. Khasian dan Manfaat Lidah Buaya. Jakarta : Penerbit Agromedia Pustaka.

Hidayah, T., Pratjojo, W., Widiarti, N. 2014. Uji Stabilitas Pigmen dan Antioksidan Ekstrak Zat Warna Alami Kulit Buah Naga. Indonesian Journal of Chemical Science, 3(2).

Hanum, T. 2000. Ekstraksi dan stabilitas zat pewarna alami dari katul beras ketan hitam (Oryza sativa glutinosa). Buletin Teknologi Pangan, XI(1): 1723.

Juniarti, D. Osmeli, dan Yuhernita. 2009. Kandungan Senyawa Kimia, Uji Toksisitas (Brine Shrimp Lethality Test) dan Antioksidan (1,1diphenyl- 2-pikrilhydrazyl) dari Ekstrak Daun Saga (Abrus precatorius I.), Makara Sains, 13 (1): 50-54.

Lazuardi, R N M. 2010. Mempelajari Ekstrak Pigmen Antosianin dari Kulit Manggis (Garcinia mangostana) Berbagai Jenis Pelarut. Skripsi. Bandung: Jurusan Teknologi Pangan, Fakultas Teknik, Universitas Pasundan.

Madene, Atmane., Jacquot, Muriel., Scher, Joel., Desobry, Stephane. 2005. Flavor Encapsulation and Controlled Release- A review. International Journal of Food Science and Technology, 41(1): 121.

Prakash, A. 2001. Antioxidant Activity. Analytical Progress, 19 (2):1-4.

Purnomo, W., Khasanah, L U., Anandito, B K. 2014. Pengaruh Ratio
Kombinasi Maltodekstrin, Karagenan dan Whey Terhadap Karakteristik Mikroenkapsulan Pewarna Alami Daun Jati (Tectona grandis L. F.). Jurnal Aplikasi Teknologi Pangan, 3(3).

Ranny, Z M. 2011. Karakterisasi Mikrokapsul Furosemin Yang Menggunakan Maltodekstrin DE 1015 Sebagai Pembawa. Skripsi. Jakarta: FMIPA, Universitas Indonesia.

Silitonga. P. dan Sitorus. B. 2014. Enkapsulasi Pigmen Antosianin dari Kulit Terong Ungu. Jurnal Kimia Katulistiwa, 3(1).

Sugindro; Mardliyati, Etik dan Djajadisastra, Joshita. 2008. Pembuatan dan Mikroenkapsulasi Ekstrak Etanol Biji Jinten Hitam Pahit (Nigela Sativa Linn.). Majalah IImu Kefarmasian, 5(2): 57- 66.

Sumarni, N K., Mauru, Y S., Puspitasari, D J., Diharnani. 2018. Efisiensi Mikrokapsul Ekstrak Etanol Kelopak Bunga Rosella (Hibiscus sabdariffa Linn) Tersalut Karaginan Kasar (Eucheuma cottoni). KOVALEN, 4(2): 201-207.

Yudiono, K., Kurniawati, L., Handini. 2016. Optimasi Ekstraksi Antosianin Ubi Jalar Ungu Dengan Metode Permukaan Respon. Prosiding SenasPro 2016. Seminar Nasional dan Gelar Produk. Malang: UMM. HIm. 20-26. 